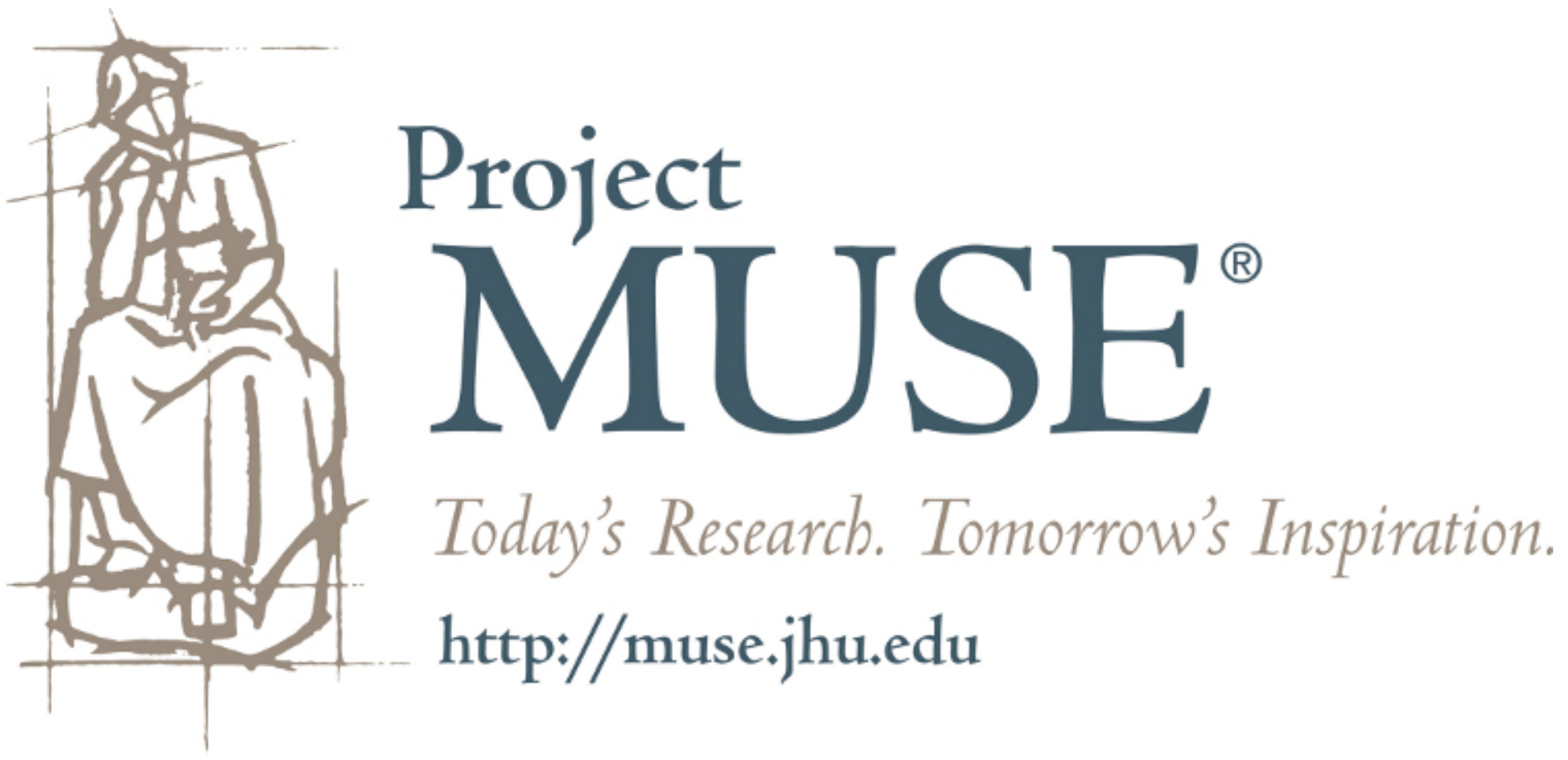




\section{What the case of}

\section{MBOSCUDA allows us}

to see more clearly is how the politics of ethnicdevelopment associations can play out when detached from the usual politics of belonging and deification of place that characterizes hometowns. 


\title{
Toward a Progressive Politics of Belonging? Insights from a Pastoralist "Hometown" Association Sam Hickey
}

\begin{abstract}
"Hometown" ethnic-development associations are accused of deepening the factional politics of belonging in Africa, and of being too easily coopted by the political forces that civilsociety organizations should in theory be challenging; however, their capacity to operate on and across multiple registers of citizenship formation means that they may be capable of achieving more progressive forms of politics. This possibility is explored through an association established to protect the rights and culture of a marginal pastoral group in Cameroon. Although the association's success remains uneven and contested, its origins in a struggle for rights, and the nonterritorial basis of its mobilization, give it an "alternative" character, which may offer clues to more progressive forms of politics in contemporary Africa.
\end{abstract}

\section{Democratization, Civil Society, and the Politics of Belonging in Africa}

Hopes that the development of civil society would be a force for democratization are particularly unrealistic. . . . With distressing frequency, the rhizomes of ethnic factionalism and patron-client politics reproduce themselves within these parties and associations, rendering them, like so much of the apparatus of the state, into ideological and institutional facades covering the reality of business as usual. (Berman 2004:51)

In many parts of Africa, "democratisation" has had quite confusing implications. Formally it brought forward multiparty politics. In practice, a much more important effect has been renewed emphasis on "autochthony" and "belonging." (Geschiere and Gugler 1998:313) 
All too often a politics of belonging is divisive and dystopian.

(Page, Mercer, and Evans 2010:347)

The current state of democratization in Africa is often depicted in terms of a disappointing failure to establish the participatory arenas, democratic norms, and accountable and responsive governance that the so-called third wave promised to deliver. Exclusionary and patronage-based politics seem to have been reestablished with relative ease, reducing the extent to which civil-society organizations have been able to flourish through a mixture of repression and cooptation. Here, the politics of belonging and autochthony seek to privilege "indigenous" groups over "nonnatives" and are increasingly seen as having a defining impact on politics across sub-Saharan Africa.

Within this context, hometown or ethnic-development associations have emerged as particularly interesting actors and offer an important window onto the contemporary politics of citizenship in Africa, in its ethnic, national, and (increasingly) global forms via the involvement of diasporic elements of ethnic groups (Mercer, Page, and Evans 2008, 2009). On the one hand, such associations have been accused of promoting "the politics of belonging at the expense of reforms encouraging both rural and urban participatory "civil society"" (Nyamnjoh and Rowlands 1998:335), and implicated in a wider process whereby rural society has "tribalized" civil society (Mamdani 1996). On the other hand, they have been praised for fulfilling not only a progressive developmental function (Mercer, Page, and Evans 2008), but also for playing a politically progressive role in promoting processes of citizenship formation and even nation-building (Evans 2010). This growing debate has tended to revolve around the extent to which a politics of place, which provides the raison d'être for hometown associations, can offer more or less progressive possibilities. Regarding what constitutes a progressive politics of citizenship in Africa, this article draws on Mahmood Mamdani's distinction between citizenship regimes founded on the rights of residence and citizenship regimes founded on territorial and cultural forms of belonging (1998:95). Where the latter tends to lead to a politics of exclusion around claims to "being native," most often in relation to land, the former holds the prospect of more universal claims, including by minority groups who contribute their labor in ways that better reflect the realities of migration. An interesting route into this debate, then, is to examine what happens in cases where ethnic development "hometown" associations are founded in a different relationship to place and land, as with associations of pastoralists, rather than farmers. The Mbororo Social and Cultural Development Association (MBOSCUDA) is the ethnic development association of a marginal pastoral group in Cameroon. The Mbororo'en have no single hometown or territory to which urban migrants can claim a common lineage, and there is no tradition of repatriating their deceased back home-a central influence on remittances in other communities (Page 2007; van Santen 1998). It is argued here that this different relationship to place, alongside other important factors, most notably their origins in a rights-based struggle against repression, has 
enabled MBOSCUDA to make significant contributions to the citizenship status and participation of this group, in ways that enable us to reimagine the democratic potential of such associations. More specifically, this case suggests that current thinking around hometown associations and the broader politics of civil society in Africa needs to be rethought in at least three ways. This would involve adopting a more clearly historicized approach, with particular reference to the earlier democratic openings of the late colonial era that helped to establish the current politics of belonging, taking seriously the multiple registers of citizenship around which much of contemporary African politics revolves, and recognizing the counterhegemonic potential of certain forms of ethnically based political action.

\section{The Politics of Belonging in Northwest Cameroon}

The (re)emergence of ethnic development associations in Cameroon since the mid-1980s, as located within a wider emphasis on the politics of belonging, was closely shaped by underlying shifts in the politics and political economy of the time. These included processes of structural adjustment and retrenchment, which forced many elites to reengage with accumulation strategies "back home" (Trager 2001), as well as those of political liberalization, which reopened political space for civil-society associations to emerge in the early 1990s. Political liberalization was soon closely curtailed, and despite repeated rounds of presidential and parliamentary elections, neither political nor civil society proved capable of capitalizing on popular discontent to depose the regime or institutionalize democratic patterns of political engagement (Nyamnjoh 1999; Takougang 2003). Rather, presidentialism and clientelism continue to pervade politics in Cameroon (van de Walle 2003), with President Biya intent on using the patronage system to maintain his dominance and political stability by coopting ethnic and regional elites (Gabriel 1999; Takougang 2003:428). The entwining of neopatrimonial with formally democratic forms of politics has become further apparent in national elections, whereby ministers are sent "home" to campaign during elections, on the understanding that it is from their place of birth and native community that they gain their legitimacy, rather than from any national standing (Nyamnjoh 1999), thus privileging ethnoterritorial citizenship as the basis of membership to the national political community.

Such developments helped fuel the "politics of primary patriotism" built around an "ideology of home," which stresses the importance of belonging to a particular native community in a particular place (Eyoh 1999; Geschiere and Gugler 1998; Geschiere and Nyamnjoh 2000). This process has been particularly apparent in relation to constitutional changes, national and local elections, and conflicts over land. Electoral campaigns frequently base their appeal on claiming to protect "indigenes" against the economic and political threat of "strangers" (Nyamnjoh and Rowlands 1998; Sharpe 1998) - a theme that resonated with the native-authority elections during the 
late colonial era. The state has played a key role here, particularly through the new 1996 Constitution, which "classifies Cameroonians into natives and foreigners (allogenes, indigenes) and makes them foreigners in their own country" (Nkwi and Socpa 1997:139). The resurgent focus on "belonging" and "autochthony" is being employed by local elites, who effectively use colonial constructions of citizenship as a means of (re)establishing local hierarchies of citizenship within multiethnic communities (Eyoh 1999:292), in ways that assure "natives" privileged access to reproductive resources and political power ahead of "strangers." As discussed elsewhere (Hickey 2007), emphasis on place-based belonging flows directly from the definition of "nativeness" imposed by the British colonial administration in this part of Cameroon.

The meaning of citizenship in relation to these political trends is far from clear, and some commentators have attempted to address this complexity through employing binary conceptualizations, whereby "urban citizens" are counterposed to "rural subjects" (Mamdani 1996) and "state citizenship" is differentiated from "ethnic" citizenship (Ndegwa 1997, echoing Ekeh 1975). Although such binary divisions clearly do not exist in reality, thinking of citizenship in relation to these different registers helps emphasize the dialectical relationships between them, which for some "foments the unique political issues that have come to characterise African politics" (Ekeh 1975: 93; echoed by Eyoh 1999:288).

Hometown associations are produced by, and help reproduce, these particular forms of politics; however, what is seldom recognized in current debates is the extent to which these trends, particularly around the local politics of belonging and tensions between ethnic and national forms of citizenship, were defining features of the democratic openings that emerged within the late colonial era, in Cameroon and elsewhere. It was at this critical moment, of state formation and civil-society openings, that such associations first gained political salience.

\title{
The Political and Developmental Role of "Hometown" Associations
}

\begin{abstract}
The ubiquitous "home town" associations are another example of the efficacy of ideologies of homes in ordering communal responses to modernization. They serve as powerful vehicles for the mobilization of resources, through levies on their members or prying of access to state resources, in order to promote the "development" of their home villages. (Eyoh 1999:291)
\end{abstract}

Hometown associations in Cameroon have their origins in the late colonial era, when the politics of civil society were defined by "ethnic," rather than "national," notions of citizenship, with numerous urban associations 
founded on the basis of protecting ethnic well-being at "home" (Achebe 1960; Chiabi 1997:191). It was here that a politics of belonging emerged, stimulated by fears that the introduction of elections for positions within native administration would lead "natives" to cede control over local politics and land to "strangers" (Geschiere 1993). This era marked the emergence of the onset of a regionalized system of patron-client politics as the basis of wider (national) political mobilization. As elsewhere in Africa (Allen 1995), the swift withdrawal of colonial powers left national movements little time to develop constituencies on any other means than patronage. In Cameroon, this was compounded by the assassination of the leader of the only potentially nationalist movement, the UPC (Joseph 1977). Taken together, these moves meant that the potential for a progressive and programmatic form of national politics was significantly curtailed before independence in Cameroon, and swiftly gave way to the politics of ethnoregional balance and patronage. The ostensible "nation-building era" in Cameroon during the 1960s and 1970s involved the banning of associations based on clanic or tribal grounds; however, these reemerged in the northwest during the 1980s (Nkwi 1997) as a response to the slowly increasing political space, the declining capacity of the state to respond to local development needs as a result of economic crisis and structural adjustment, and the related movement of urban elites toward rural homes as part of livelihood diversification. In 1990, the law changed directly, allowing such associations to (re)emerge fully.

To the extent that hometown associations are characterized by their straddling of urban-rural arenas, they have once more become emblematic of the form of democratic openings and associational renewal that emerged in Cameroon over the 1990s. Informal networks were important within civic life in Cameroon (Monga 1996:157), and the spread of popular protest in Cameroon was initially facilitated by word of mouth by those traveling back from major urban centers to rural areas, particularly students (Krieger and Takougang 1998:124). The urban-rural dimensions of popular protest, a key characteristic of popular struggles in Africa during the early 1990s, denoted a shift from "rural to urban protest, from peasant society ('the people') to civil society ('the citizens') . . [involving] the organized strength of professional associations, trade unions and churches" (Mamdani 1998:84). In Cameroon, urban-based human-rights organizations, students, lawyers, intellectuals, journalists, and certain church leaders promoted democratic reform; however, given the apparent failure of the 1990s to institutionalize a "modern" urban-based civil society, the associational form that emerged as the most capable of mediating between urban migrants and rural communities-between Mamdani's (1996) "urban citizens" and "rural subjects"—was the hometown, or cultural and development associations. This arguably led to the "replacement of political parties by ethnicized elite associations as the prime movers in local regional politics" (Nyamnjoh and Rowlands 1998:321), and for linking local concerns with national politics, whereby "these urban associations see themselves playing a brokerage function vis-à-vis the state and local communities" (Fisiy and Goheen 1998:392). More recently, as the 
operation of state politics takes on extraterritorial characteristics under globalization and associated trends of transnational migration, hometowns have become key nodes within wider diasporic networks (Kerlin 2000; Mohan 2008). This transnationalization of hometowns has been further deepened by their increased involvement with international development organizations keen to promote participatory and locally driven forms of development (Hickey 2002; Mercer, Page, and Evans 2008).

The ubiquity and character of such associations within an otherwise weak civic arena raises important questions concerning their capacity to secure an autonomous arena of citizenship participation for its members, and their wider impact on the democratic politics of citizenship. In particular, one close observer of social movements in Africa distinguishes their political character in relation to struggles for democracy, whereby "movements that struggle for rights (for equality) must be distinguished from those who fight for privileges (for advantage); the former must be supported, the latter isolated" (Mamdani 1990:57). The initial evidence on hometown-development associations in Cameroon, and more broadly across West Africa, appears to be ambiguous on this point. For critics, the epistemological and ideological vacuity of the discourse of "belonging" renders hometowns vulnerable to manipulation and cooptation (Geschiere and Nyamnjoh 2000:424; Nyamnjoh and Rowlands 1998), most notably by states concerned with extending their grip on power (Woods 1994). To the extent that they employ "vitriolic theories of inequality" to make their case, they undermine the possibility of a civic discourse emerging (Monga 1996:92). Their membership structure and inner workings often exhibit undemocratic and patriarchal tendencies, which exclude already marginal groups (Honey and Okafor 1998b:12), including strangers who do not fit the discourse of nativeness. Here, hometowns distract political agency away from broader democratic struggles and reinforce the politics of ethnoregional balance, patronage, and belonging. As Page, Mercer, and Evans note for Cameroon, "The initial motivation for emphasizing the rights of autochthons was to undermine multi-party democracy" (2010:364).

More positive readings suggest that these associations are often genuine providers of social and physical development, infrastructure, and security, in contexts where the state has been unwilling or unable to provide such public goods (Henry 2004; Honey and Okafor 1998a; Kerlin 2000; Mercer, Page, and Evans 2008; Nkwi 1997). They offer participatory institutions of indigenous civil society (Hutchful 1995:68), providing members with formal and informal means of participation (Barkan, McNulty, and Ayeni 1991: 478; Evans 2010; Pratten and Baldo 1995). Much of this may result from the ethnically motivated mobilizations (Trager 2001:268), and such associations may mediate conflict between ethnic groups (Agbese 1998). More broadly, hometowns may act as agents of "civic virtue" (Barkan, McNulty, and Ayeni 1991:481), through leadership training, voter education, and public debate. Some may oppose the predations of the state (Honey 1998:150), including associations in northwest Cameroon that adopted an oppositional stance to the regime (Nkwi 1997). 
Ethnic-development associations, and their hometown variants in particular, are thus both celebrated and damned regarding their role as mediators of citizenship formation in contemporary Africa, whether in terms of identity, culture, and ethnicity as the means of political mobilization (ethnic citizenship), development (socioeconomic rights), or inclusion in the national polity (the status and rights associated with national citizenship). Of essence to both sides of the debate around hometowns is their linking of political and developmental claims to a territorially defined home, which is thereby called upon to act as the crucible of ethnic and national citizenship, linking local mobilizations to national inclusion. The above debates thus reflect wider ones, which concern the extent to which a politics of place can be progressive or not; however, by focusing on a particular type of ethnic development association-one that represents a pastoralist community in Cameroon who have a necessarily different relationship to land compared to their "native" counterparts-we can investigate how the politics of such associations alters when place no longer plays a central role in the claims being made.

\section{Caught at the Crossroads: The Mbororo Fulani as Citizens in Northwest Cameroon}

The Mbororo Fulani of Cameroon, whose ethnic development association we examine here, have historically been marginal too or adversely incorporated within the dominant processes and constructions of citizenship in Cameroon. ${ }^{1}$ A central problem is a tendency to render the groups that have a different relationship to land as somehow other or incomplete as members of both local and national political communities-an exclusionary and subordinating dynamic, which affects not only pastoralists, but also hunter-gatherers (Leonhardt 2004). The Mbororo'en arrived from Nigeria in 1916 as a seminomadic group. Their livelihood as pastoralists, dispersed and fragmented sociopolitical structures, and attachment to Islam distinguished them from the "native" farming populations. As the last social group to arrive into the Grassfields before the implementation of British native administration in the 1920s, they have typically been viewed as strangers by their neighbors and successive state regimes, and were denied a native authority of their own. ${ }^{2}$ Social relations between them and local farmers vary across the province, but are often closely informed by a sense of otherness and reserve, stemming from the Mbororo Fulani cultural code of pulaaku, ${ }^{3}$ and a sense in which even the term Mbororo has been used (until recently) by farming groups to denote a lack of civilization among the Mbororo'en. As a result, the Grassfields Mbororo'en stood at the margins of citizenship for most of the twentieth century, incorporated into ethnoterritorial processes of state and civil-society formation through patron-client ties, rather than as of right. Under the forms of politics that have (re)emerged in Cameroon since the early 1990s, they have faced increased insecurity in regard to land 
and physical safety, and, despite efforts to engage with "democratic" forms of citizenship, they remain subject to sustained human-rights abuses. Dependent on the administration for access to land, and for the resolution of ubiquitous farmer-grazier conflicts, they have been seen as political enemies by opposition-supporting farming groups and made subject to violence around elections (Hickey 2007).

From the late 1980s, the localized patron-client relationships of the Grassfields Mbororo'en became extended into a national, and far more predatory, political environment. Their tendency to forge informal, patronagebased relationships, along with their weak political voice, relative wealth in cattle, and low level of internal political organization, all left them vulnerable to the attentions of a particular state patron who was seeking to secure his position within the ruling party. This neopatrimonial engagement, which intensified under the pressure of democratization in the early 1990s, marked a significant watershed for Mbororo inclusion in Cameroon's wider political community. In particular, it has been characterized by three key, overlapping phases: a period of predatory patronage (1986-1996); a shift to more benevolent forms of patronage (1994-2002); and the current period (2002-), whereby clientelistic relations have become moderated by stronger forms of (arguably) citizenship-based interactions.

The period of predatory patronage began in 1986 with a campaign of human-rights abuses and land confiscation against Mbororo communities in the northwest, carried out by a wealthy industrialist and member of the ruling party's central committee, Alhadji Ahmadou Baba Danpullo, who cleared several Mbororo herders off their land, and used their cattle to establish a personal ranch. ${ }^{4}$ For several years, he continued to evict Mbororo families from this ranch and have their compounds bulldozed without compensation (Asaah 1996). Protests led to arrests and imprisonment. This project of repression intensified during the 1990s, as "the central committee of the CPDM [sent] its leaders back to their regions and villages to campaign" (Nyamnjoh 1999:106), and Alhadji Baba focused on the Grassfields Mbororo'en as his client group. He adopted several other further neopatrimonial tactics in his bid to establish political control over them, including gaining a presidential decree to form an alkali (traditional Muslim) court, which he had instated next to his ranch; his "marriage" and divorce of Mbororo women as a means of his own cultural ingratiation and the subjugation of local Mbororo'en; and sustained attacks on any autonomous organizational capacity promoted among the Mbororo'en, including traditional leadership, cattle cooperatives, and (as discussed here) development associations.

\section{MBOSCUDA: A Movement for Inclusion or for Rights?}

A founder of MBOSCUDA states that it was "Alhadji Baba's activities [that] brought Mbororo people to some sort of consciousness, political consciousness, as to their problems as a people" (interview, July 2000). This catalyzed 
the formation of a cultural and development association in 1992, which the same founding member describes as "the social movement of a once nomadic people." Its aims are to develop a closer sense of ethnic citizenship while challenging the exclusion of the Mbororo'en within the national political community. The idea of forming an Mbororo association arose in urban centers throughout the northwest during discussions between Mbororo students and Mbororo'en engaged in trading and other forms of waged employment. The sense of cultural discontinuity felt among the youth in towns catalyzed a desire to preserve Mbororo culture, reflecting an "identity crisis" further exacerbated by negative perceptions of the term Mbororo. Importantly, some of the founders were closely involved in the wider democratic movements of the time, including the student riots in Yaounde and opposition rallies in Bamenda; however, it was the renaissance of ethnic development associations in Cameroon that inspired the formation of MBOSCUDA as a vehicle to protect the rights and promote the culture of the Mbororo'en, with a particular focus on women and the youth.

MBOSCUDA sought to establish itself primarily as a grassroots organization within a broader hierarchical structure that follows Cameroon's administrative structure through national, provincial, divisional, and subdivisional levels, down to women's groups and men's groups (fahdas) at the local level. In accordance with the tenets of popular democracy, a general assembly forms the apex of MBOSCUDA's decision-making structure, and has policymaking powers, though in reality the association's agenda and policy goals were largely established at the executive level. Membership in the general assembly is open to all Mbororo'en who register and pay membership fees, and national and provincial executives are constitutionally accountable to elections at general assemblies. Grassroots participation is seen by most founding executive members as the key to their legitimacy and, in the Northwest Province of Cameroon, where the association is most active, the annual general assemblies during the 1990s were regularly attended by hundreds and sometimes thousands of members (and provide a key focus for this paper). MBOSCUDA's capacity to mobilize its constituency in such ways reflected the strong sense of ownership that members felt toward the association, though this did not necessarily extend to the regular payment of membership fees.

MBOSCUDA's initial activities focused on conscientization visits and rallies across the province, the creation of local constituent groups, and efforts to develop Anglo-Arabic schools. Since 1998, with the support of international development organizations, MBSOCUDA has provided increased support for its women's groups, focusing in particular on functional and political literacy, capacity building, microfinance, and enterprise development. Latterly, these efforts have extended into the more political realm of human-rights work, particularly through a paralegal extension program designed to challenge the exploitative relationships between the local state and Mbororo graziers that emerge most frequently in relation to farmer-grazier conflicts (Duni et al 2009). National citizenship rights and 
status are promoted via advocacy, civic education, and voter registration, while at general assemblies an emphasis on national and ethnic forms of belonging are apparent, with football tournaments in line with Cameroon's one truly shared and national concern on the one hand, and traditional displays of horse-riding on the other.

MBOSCUDA was thus formed as a response to problems of "exclusion," forged through a direct engagement with both the neopatrimonial and the democratic, the modern, and a reimagination of the traditional, and involving shifts between the urban and the rural. In this, it shares not only the origins of most hometown associations, but also the founding characteristics of most social movements, in that its origins are in the actions of a disenfranchised "elite," seeking to gain inclusion for their group: it has a specific identity, an adversary, and a societal goal (Castells 1997). At its most radical, MBOSCUDA's aim is "to change the nature and balance of power relationships that have helped to marginalise and sideline Mbororo people" (MBOSCUDA 1998). If strengthening ethnic unity was a key concern at the outset "the moment Baba stepped in, it also became a question of defending Mbororo rights" (interview with MBOSCUDA founder, July 2000). The form this movement took, and its implications for citizenship among the Mbororo'en, strongly reflected these influences. General assemblies not only offer such associations a means by which "rural subjects" can hold "urban citizens" to account (Pratten and Alibaldo 1995), but also of securing internal unity and establishing a wider profile vis-à-vis the state, and are thus significant windows onto their political character.

\section{General Assemblies as Windows onto Citizenship Formation}

Between 9 and 12 December 1994, the largest gathering of Mbororo'en in Cameroon ever held occurred in the Northwest Province at MBOSCUDA's inaugural national general assembly. Despite Alhadji Baba's efforts to prevent the meeting, the main traditional leader of the Mbororo'en in the northwest, the Lamido of Sabga, greeted guests of honor, including more than a hundred ardo'en (Mbororo traditional leaders) and esteemed guests, including a direct representative of the prime minister, the Governor of Northwest Province, the local senior divisional officer, local traditional chiefs, representatives of other cultural and development associations and a lawyer from the Cameroon Bar Association. For a founding member, the wide-ranging media publicity that this received meant that "Whatever the intended or unintended message, two things were clear: the Mbororo'en are a formidable force and that MBOSCUDA was their representative organization" (interview with author)—claims that would be closely contested over the following decade.

The assembly reflected MBOSCUDA's engagement with ethnic and national processes of citizenship formation. That the meeting was held in Sabga, where the first Mbororo to arrive in the Grassfields had settled, reflected an attempt to engage with the ideology of home (Eyoh 1999) and a 
resurgence of ethnic-territorial politics in Cameroonian political discourse (Nyamnjoh 1999:105-111). The assembly was built around expressions of culture, cultural unity, and mass Mbororo participation as a means of developing a stronger sense of community and primary patriotism. This, alongside the more direct overtures made to the invited representatives of political and civil society, was intended as a means of raising the visibility of this previously marginal group and securing Mbororo status and rights within the wider political community.

The immediate outcome was unpromising, and the mid-1990s were characterized for MBOSCUDA by a series of conflicts with Alhadji Baba, who continued to obstruct the association from organizing and providing services, such as education, to Mbororo communities, and was closely implicated in the arrest and detention of four key MBOSCUDA leaders in 1996 on charges of defamation against himself. All four were released through the efforts of local and international human-rights activists. This alignment with democratic forces at the local and international level looked set to secure MBOSCUDA's status as a social movement of "rights" rather than "privileges" (Mamdani 1993).

\section{From Predatory Patronage to Benevolent Clientelism}

By the time of the 1998 general assembly (Northwest), a new set of challenges had emerged for MBOSCUDA, relating less to the exclusion and repression of its members than to the difficulties of maintaining autonomy and purpose in the face of apparently more benign and inclusive forms of clientelism. This move was characteristic of MBOSCUDA's relations with international development as well as the state. The encounter with development agencies involved a series of funded initiatives largely with MBOSCUDA's women's groups (e.g., microcredit and adult literacy). On the one hand, the training provided by some international nongovernmental organizations resonated with the sense of exclusion and subordination that underpinned MBOSCUDA's emergence, as with those participatory methodologies that emphasized a radical, Freirean understanding of "structures of oppression" (Hickey and Mohan 2005); on the other hand, the creation of an elite development cadre, the redrawing of lines of accountability within MBOSCUDA upward toward funding "partners" and the repackaging of empowerment as a project-based activity all threatened to detach the association from its more political goals (Hickey 2002).

Relations with the state were significantly altered around MBOSCUDA Northwest's November 1998 Provincial Assembly, which saw a challenge to the erstwhile hegemony of Alhadji Baba as the sole state patron of the Mbororo'en in the Northwest. First, the national vice president of MBOSCUDA and a long-time member of the ruling party used his keynote speech to introduce the theme of political inclusion, stressing the need for closer Mbororo-state relations, and for the Mbororo'en to represent themselves in government. This sentiment was given extra weight by the presence of a 
government minister who had been prospecting the Grassfields Mbororo'en as a political constituency since the 1994 Sabga assembly, leading to an inevitable battle of patronage as revealed by a sensationalist press headline, "Alhadji Baba at war with Peter Abety" (Political Punch 1998). Minister Abety claims to have intervened in several ways to assist his prospective client group, including securing the release of Mbororo men imprisoned by Baba, the enrollment of Mbororo students into the National School of Administration and Magistrates, and support of several infrastructure projects around Sabga (interviews with author, May 2000 and November 2004).

Within weeks of the general assembly, the MBOSCUDA national vice president was appointed as an attaché at the secretariat within the Social and Cultural Division of the Presidency. This appointment was heralded on both sides as a watershed in Mbororo-state relations, and celebratory receptions were held at the key bases of traditional authority among the Mbororo'en in the northwest. At the Sabga celebrations, the appointment was welcomed as an act by the state that acknowledged "not only the existence of the Mbororo'en, but their being part and parcel of the republic; this act symbolizes the acceptance of the beginning of a new social contract between the Mbororo people and the Cameroon state" (interview, MBOSCUDA founder, August 1999).

Such political appointments are characteristic of the politics of ethnoregional balance in Cameroon and are largely meaningless in material terms (Nyamnjoh 1999). At worst, they allow the state to blame any failings for the representation of a group's interests on the appointee. Moreover, this created a significant challenge for MBOSCUDA regarding its political positionality. At the Sabga reception for the MBOSCUDA appointee, traditional leaders declared that "we the Mbororos of Cameroon and Northwest Province in particular, unanimously agree to irrevocably support His Excellency President Paul Biya in the tedious and noble task of Nation building" (MBOSCUDA 1999a). Minister Abety, meanwhile, clearly saw MBOSCUDA as a conduit through which he and the ruling party could reach Mbororo people, capitalizing on the fact that it "can reach people in a way that we cannot, and get to them on the issues that we want expressing" (interview with author, May 2000).

MBOSCUDA generally welcomed the respite that their new patrons gave them from Alhadji Baba's attentions (MBOSCUDA 1999b, n.d.), but some leading members sought to secure the association's autonomy from the regime. At the 1999 national general assembly, two members who politically opposed the ruling party were appointed as vice presidents on the national executive. Unlike other associations in Cameroon, this move did not result in a splintering of MBOSCUDA along party political lines (Nyamnjoh and Rowlands 1998); rather, it highlighted the tension for such associations between a push for inclusion within the state on the one hand, and seeking to advance democratization through a discourse of rights on the other. 


\section{From Benevolent Clientelism toward Negotiated Citizenship?}

By the time of the 2002 general assembly (Northwest), such a strategy was undone. Alhadji Baba had reemerged as a predatory force, while Minister Abety lost his executive position in one of the President's perennial ministerial reshuffles. Baba's renewed harassment and detention of MBSOCUDA leaders and efforts to prevent mass MBOSCUDA gatherings culminated in the use of state security forces to arrest four Mbororo youths for seeking to resist Baba's further encroachment onto Mbororo grazing land. In a sequence of abuses of rights and due process, one was tortured, and all were held for prolonged periods without trial. At the 2002 MBOSCUDA northwest general assembly, Baba was denounced as a "terrorist" in a post-9/11 speech by the MBOSCUDA provincial president, and the presence of both the national opposition leader and the governor of the Northwest Province reflected both the growing profile of MBOSCUDA as an association, and its capacity to engage multiple strategies to achieve its end of securing rights for its membership. The capacities of this organizational form were further revealed within the specific campaign to secure the release of the prisoners. Here, the Yaounde branch of the association undertook high-profile media campaigns and sought direct audiences with key government figures. The Douala branch provided important financial support, while the Northwest branch reengaged its local and international human-rights networks, drawing for the latter on the contacts of two founder members now based in the United Kingdom. The result strongly enforced the extent to which the Mbororo'en could protect their rights and status as citizens. Not only were the prisoners released (on 23 March 2004), but the state felt pressured to establish a national commission into relations between Alhadji Baba and the Mbororo'en. This commission heard scores of verbal submissions from those Mbororo affected by Baba's predatory campaign, publicly shaming him in the process.

This trajectory was reflected in Mbororo relations with international development work. Here, project-based development interventions were increasingly becoming realigned with MBOSCUDA's more political goals of promoting rights. A particular focus has been a paralegal extension initiative which seeks to protect the Mbororo'en from low-level exploitation at the hands of state agents well versed in the practice of exploiting cattle from the patron-friendly Mbororo'en, particularly during farmer-grazier conflicts. These paralegal activities have had some striking successes, with divisional officers, Mbororo graziers, and independent observers all noting significant changes in Mbororo-state relations (Duni et al. 2009). These include a greatly reduced level of forced payments by graziers and the (related) increased ability to negotiate with the administration, a stronger sense of self- and group-empowerment, increased levels of legal and political literacy, and the removal of exploitative middlemen in dealings with the administration. 
As a social movement, MBOSCUDA has thus adopted a strategy of seeking inclusion while mounting resistance based on a struggle for rights. To the extent that the struggle for rights has tended to eclipse the struggle for inclusion, it has directly challenged the prevailing neopatrimonial order and become aligned with other social movements characterized by their resistance to hegemonic forces. Importantly, these rights-based claims have been on the more progressive grounds of residence rather than belonging (Mamdani 1998). From this perspective, elements within MBOSCUDA have sought to reach out to other groups beyond their own ethnic group, whether in terms of joint cases with farmers who have had their land damaged by Baba's encroachment, or through attempting to forge an alliance with other marginal groups in Cameroon, such as the forest people (Leonhardt, 2004). This raises the prospect, albeit distantly in the case of Cameroon, that the particularistic concerns of social movements can be transformed into more universalist gains through the political process of advocating for minority rights and issues (Foweraker and Landman 1997).

\section{Final Thoughts: The Progressive Politics of Hometowns}

The politics of hometown associations are closely shaped by the particular historical moments that led them to flourish, particularly the democratic openings of the late colonial era and the more recent wave of political liberalization. The late colonial era saw the establishment of certain patterns of civil-society politics, whereby the apparently universal discourse of rights generated fears that such equality would open the way for nonnative groups to claim control of local politics and resources, particularly land. Along with the concurrent splintering of any nationalist or programmatic basis for political mobilization, this helped give rise to marginalizing discourses of belonging. Such patterns broadly reemerged in the 1990s, when the factional and deepening politics of neopatrimonialism became entwined with new democratic openings and the politics of belonging. Hometown associations returned to give expression and form to these forms of politics, and to be caught once again in their ambivalence. Such associations are "neither saintly nor satanic" (Honey 1998:153); rather, they can accommodate both the progressive and exclusive political discourses that permeate and define debates over citizenship in Africa, and can be seen as one of the key sites where the contradictions of citizenship in Africa converge and are negotiated-particularly between the national and the ethnic, the urban and the rural, and the traditional and the modern.

What the case of MBOSCUDA allows us to see more clearly is how the politics of ethnic-development associations can play out when detached from the usual politics of belonging and deification of place that characterizes hometowns. The "placelessness" of MBOSCUDA's membership offered the association an opportunity to promote citizenship based not on "belonging," but on the more progressive grounds of "residence" (Mamdani 1998). Where 
a retreat to terroir is so often associated with new processes of elite power accumulation and regressive forms of "exclusionary" politics in Cameroon (Page, Mercer, and Evans 2010), historically landless and late-arriving groups are forced to use wider, potentially more inclusive frames of reference for their citizenship claims.

To the extent that MBOSCUDA has adopted politically progressive positions at various points in time, this also derives from their memberships' particular status as citizens at the margins and from the need to challenge the human-rights abuses emanating from a particular actor within the broader neopatrimonial political system (Hickey 2007). In a process recognized by those studying the politics of peripheral groups in Africa, marginality offers a space from which exclusion can be challenged, and within which alternative forms of citizenship can be imagined, defined, and sometimes promoted (Fardon 1988; Jackson 1999). Some ethnic-development associations can thus meld together the multiple forms of citizenship that permeate and characterize postcolonial African politics, and forge linkages between the politics of recognition and the politics of rights (Englund 2004) in potentially progressive ways.

\section{ACKNOWLEDGEMENTS}

This research was undertaken with financial assistance from a U.K. Department for International Development research grant, a doctoral scholarship from Staffordshire University, and generous donations from two valued mentors.

NOTES

1. See Hickey (2007) for a more detailed account of citizenship formation among the Mbororo'en.

2. Earlier research (Frantz 1986) shows that the current Mbororo population for the whole province could be placed at around 80,000 , out of a total of more than 1.5 million. Under the terminology employed here, the Grassfields Mbororo'en (pl. Mbororo) stands for those Mbororo'en who reside within the Northwest Province. The Grassfields Mbororo'en can be distinguished within Cameroon from the state-forming Fulbe of Northern Cameroon, with whom President Ahidjo was affiliated, and other branches of the pastoral Fulani, such as those the Wodaabe (Burnham 1996). Significant divisions occur among the Grassfields Mbororo'en in terms of origin, clan, age, and gender.

3. The cultural code of pulaaku helps maintain an ethnic boundary around the Fulani category, and has been described as "an ideology of racial and cultural distinctiveness and superiority that ranks the Fulani above all other ethnic groups" (Burnham 1996:106).

4. Baba was at this stage the proprietor of a successful wheat-importing company, Société Minotiries de Cameroon (a former parastatal), and now owns a wheat factory in South Africa. He was probably appointed during a ruling-party conference in 1985, when several businessmen 
joined the central committee-a move that further secured the "osmosis between the two spheres" of politics and economics in Cameroon (Bayart 1993:94-95).

\section{REFERENCES CITED}

Achebe, Chinua. 1960. No Longer At Ease. Oxford: Heinemann.

Agbese, Pita. O. 1998. Hometown Associations and Conflict Management: The Experience of the Agila Development Association. In Hometown Associations: Indigenous Knowledge and Development in Nigeria, edited by Rex Honey, and Stanley Okafor. London: Intermediate Technology Publications.

Allen, Chris. 1995. Understanding African Politics. Review of African Political Economy 65: 301-320.

Asaah, Florence. 1996. Good Governance in Cameroon. Conference paper from a human rights activist Bamenda. 24 May.

Barkan, Joel D., Michael L. McNulty, and M. A. O. Ayeni. 1991. "Hometown” Voluntary Associations, Local Development, and the Emergence of Civil Society in Western Nigeria. Journal of Modern African Studies 29(3):457-480.

Bayart, Jean-Francois. 1993. The State in Africa: The Politics of the Belly. London: Longman.

Berman, Bruce. 2004. Ethnicity, Bureaucracy and Democracy: The Politics of Trust. In Ethnicity and Democracy in Africa, edited by Bruce Berman, Dickson Eyoh, and Will Kymlicka. Oxford: James Currey.

Burnham, Philip. 1996. The Politics of Cultural Difference in Northern Cameroon. Edinburgh: Edinburgh University Press.

Castells, Manuel. 1997. The Power of Identity. London: Blackwell.

Chiabi, Emmanuel. 1997. The Making of Modern Cameroon: Vol. 1: A History of Substate Nationalism and Disparate Union, 1914-1961. Lanham, Md.: University Press of America.

Duni, Jeidoh, Robert Fon, Sam Hickey, and Nuhu Salihu 2009. NGOs, Social Movements and Paralegal Extension in North West Cameroon: From Clientelism to Citizenship at the Margins? In Rights, Wrongs, and Realities: The Potential and Pitfalls of Rights-Based Approaches to Development, edited by Sam Hickey and Diana Mitlin. Washington, D.C.: Kumarian.

Ekeh, Peter. 1975. Colonialism and the Two Publics: A Theoretical Statement. Comparative Studies in Society and History 17(1):91-117.

Englund, Harry. 2004. Recognizing Identities, Imagining Alternatives. In Rights and the Politics of Recognition in Africa, edited by Harry Englund and Francis B. Nyamnjoh. London: Zed Books.

Evans, Martin. 2010. Primary Patriotism, Shifting Identity: Hometown Associations in Manyu Division, South-West Cameroon. Africa 80(3):397-425.

Eyoh, Dickson. 1999. Community, Citizenship, and the Politics of Ethnicity in Post-Colonial Africa. In Sacred Spaces and Public Quarrels: African Cultural and Economic Landscapes, edited by Paul T. Zeleza and Ezekiel Kalipeni, 271-300. Ewing, N.J.: Africa World Press.

Fardon, Richard. 1988. Centre, Periphery, Boundary: Some Problems with Spatialising Problems. In Proceedings/Contributions, Conference on the Political Economy of Cameroon: Historical Perspectives, edited by Peter Geschiere and Piet Konings. 2 vols. Leiden: African Studies Centre.

Fisiy, Cyprien, and Miriam Goheen. 1998. Power and the Quest for Recognition: Neo-Traditional Titles amongst the New Elite in Nso, Cameroon. Africa 68(3):383-402. 
Foweraker, Joseph, and Todd Landman. 1997. Citizenship Rights and Social Movements: A Comparative and Statistical Analysis. New York: Oxford University Press.

Frantz, Charles. 1986. Fulani Continuity and Change Under Five Flags. In Pastoralists of the West African Savannah, edited by Mahdi Adamu and Anthony H.M Kirk-Greene, 16-39. Manchester: Manchester University Press and International African Institute.

Gabriel, Jurg M. 1999. Cameroon's Neopatrimonial Dilemma. Journal of Contemporary African Studies 17(2):173-196.

Geschiere, Peter. 1993. Chiefs and Colonial Rule in Cameroon: Inventing Chieftancy, French and British Style. Africa 63(2):151-175.

_ Belonging and Identification. Africa 68(3):309-319.

and Francis Nyamnjoh. 2000. Capitalism and Autochthony: The Seesaw of Mobility and Belonging. Public Culture 12(2):423-452.

Henry, Leroy. 2004. Morality, Citizenship and Participatory Development in an Indigenous Development Association: The Case of GPSDO and the Sebat bet Gurage of Ethiopia. In Participation: From Tyranny to Transformation? edited by Sam Hickey and Giles Mohan. London: Zed Books.

Hickey, Sam. 2002. Transnational NGDOs and Participatory Forms of Rights-Based Development: Converging with the Local Politics of Citizenship in Cameroon. Journal of International Development 14(6):841-857.

2007. Caught at the Crossroads: Citizenship, Marginality and the Mbororo Fulani In Northwest Cameroon. In Making Nations, Creating Strangers: States and Citizenship in Africa, edited by Sara Dorman, Daniel Hammet, and Paul Nugent. Leiden: Brill.

and Giles Mohan 2005. Relocating Participation within a Radical Politics of Development: From Practice to Theory. Development and Change 36(2):237-262.

Honey, Rex. 1998. Structure, Agency and the Modification of Indigenous Institutions. In Hometown Associations: Indigenous Knowledge and Development in Nigeria, edited by Rex Honey and Stanley Okafor. London: Intermediate Technology Publications.

__ and Stanley Okafor, eds. 1998a. Hometown Associations: Indigenous Knowledge and Development in Nigeria. London: Intermediate Technology Publications.

— Hometown Associations: Indigenous Knowledge and Development in Nigeria, edited by Rex Honey and Stanley Okafor. London: Intermediate Technology Publications.

Hutchful, Eboe. 1995. The Civil Society Debate in Africa. International Journal 51:54-77.

Jackson, Cecile. 1999. Social Exclusion and Gender: Does One Size Fit All? European Journal of Development Research 11(1):125-146.

Joseph, Richard A. 1977. Radical Nationalism in Cameroon: Social Origins of the U.P.C. Rebellion. London: Oxford University Press.

Kerlin, Michael D. 2000. New Agents of Socio-Economic Development: Guinea-Bissauan Hometown Associations in Portugal. South European Society \& Politics 5(3):33-55.

Krieger, Milton, and Joseph Takougang. 1998. State and Society in Africa: Cameroon at the Crossroads. Boulder, Colo.: Westview Press.

Leonhardt, Alec. 2004. The Baka and the Anti-State: Between Autochthony and Citizenship. Paper given at the ASA-US Biennial Conference, New Orleans.

Mamdani, Mahmood. 1990. State and Civil Society in Contemporary Africa: Reconceptualising the Birth of State Nationalism and the Defeat of Popular Movements, Africa Development 15(3-4):47-70. 
- 1993. Social Movements and Democracy in Africa. In New Social Movements in the South: Empowering the People, edited by Ponna Wignaraja. London: Zed Books.

- 1996. Citizen and Subject: Contemporary Africa and the Legacy of Late Colonialism. London: James Currey.

1998. Africa: Democratic Theory and Democratic Struggles. In Peoples'Rights: Social Movements and the State in the Third World, edited by Manoranjan Mohanty et al. New Delhi: Sage.

MBOSCUDA. 1998. A Six Year Balance Sheet. Speech given at the Fifth Northwest Provincial Ordinary General Assembly of MBOSCUDA, 11 July 1998, Fundong, NWP. Nuhu Salihu.

MBOSCUDA. 1999a. Motion of Support to H. E. President Paul Biya. Signed Lamibe Sabga and Dahirou, and Ardo Umarou, at the Civic Reception in Honour of Mr Manu Jaji Gidado, Sabga 2 July 1999.

MBOSCUDA. 1999b. Rejoinder to an article in issue No. 760, May 24-25 1999: Mbororos in the Northwest Accuse Abety of Manipulation, Petition Prime Minister. Letter to The Herald. Signed President MBOSCUDA, Secretary General Ardos Forum and Lamido of Sabga.

MBOSCUDA. N.d. False Accusations against Dr. Peter Abety, Minister in Charge of Missions at the Presidency of the Republic. Letter from MBOSCUDA NW, sent to the newspapers La Nouvelle Expression and Le Jeune Detective.

Mercer, Claire, Ben Page, and Martin Evans. 2008. Development and the African Diaspora: Place and the Politics of Home. London: Zed Books.

—_ - 2009. Unsettling Connections: Transnational Networks, Development and African Home Associations. Global Networks 9(2):141-161.

Mohan, Giles. 2008. Cosmopolitan States of Development: Homelands, Citizenships, and Diasporic Ghanaian Politics. Environment and Planning D: Society and Space 26:464-479.

Monga, Celestin. 1996. The Anthropology of Anger. Boulder Colo.: Lynne Rienner.

Ndegwa, Stephen. 1997. Citizenship and Ethnicity: An Examination of Two Transition Movements on Kenyan Politics. American Political Science Review 91(3):599-616.

Nkwi, Paul. N. 1997. Rethinking the Role of Elites in Rural Development: A Case Study From Cameroon. Journal of Contemporary African Studies 15(1):67-86.

— and Rule. In Regional Balance and National Integration in Cameroon: Lessons Learned and the Uncertain Future, edited by Paul Nkwi and Francis B. Nyamnjoh. Leiden: ASC/Yaounde: ICASSRT.

Nyamnjoh, Francis. B. 1999. Cameroon: A Country United by Ethnic Ambition and Difference. African Affairs 98:101-118.

_ Africa 68(3):320-337.

Page, Ben. 2007. Slow Going:The Mortuary, Modernity and the Home-Town Association in Bali-Nyonga, Cameroon. Africa 773:419-441.

_ Claire Mercer, and Martin Evans. 2010. Revisiting the Politics of Belonging in Cameroon. Africa 803:345-370.

Political Punch. 1998. Alhaji Baba at War with Peter Abetty. Vol.3, No.122

Pratten, David, and Suliman Ali Baldo. 1995. "Return to Roots": Processes of Legitimacy and Accountability in Sudanese Migrant Associations. In NGOs: Performance and Accountability: Beyond the Magic Bullet, edited by Michael Edwards and David Hulme. London: Earthscan.

Sharpe, Barry. 1998. First the Forest: Conservation, Community and Participation in South-West Cameroon. Africa 68(1):25-45.

Takougang, Joseph. 2003. The 2002 Legislative Election in Cameroon: A Retrospective on Cameroon's Stalled Democracy Movement. Journal of Modern African Studies 41(3):421-435. 
Trager, Lynne. 2001. Yoruba Hometowns: Community, Identity, and Development in Nigeria. Boulder, Colo., and London: Lynne Reinner.

van de Walle, Nicholas. 2003. Presidentialism and Clientelism in Africa's Emerging Party Systems. Journal of Modern African Studies 412:297-321.

van Santen, Jose C. M. 1998. Islam, Gender and Urbanisation among the Mafa of North Cameroon: The Differing Commitment to Home among Muslims and Non-Muslims. Africa 68(3):403-424.

Woods, Donald. 1994. Elites, Ethnicity, and Home-Town Associations in the Cote d'Ivoire: An Historical Analysis of State-Society Links. Africa 64(4):465-483. 